\title{
The Commonwealth of Literacy Literacy, Distance Education and Refugees
}

Flora MacDonald was the guest speaker at a seminar organized by the Centre for Refugee Studies on October 22, 1990 at McLaughlin College, York University. Canada's former Minister of Employment and Immigration and of External Affairs is now a coordinator with the Commonwealth of Learning, an autonomous institution created by the Commonwealth of Nations in 1987. Her personal interest in refugees and education has been integrated in her current project, which is to coordinate the setup of distance education, literacy and literacy training programs for refugees in southern Africa. The seminar brought together experts in fields ranging from distance education, literacy, literacy training, refugees to international development. The seminar was designed with the intention of giving initial feedback to the Commonwealth of Learning's plan to set up programs for refugees in Southern Africa as well as to set up an informal network of experts to assist in the general direction of the Centre's project."

\section{Historical Background}

Flora MacDonald: The 1970s and 1980s saw a cutback in the number of students coming to Canada for university studies from abroad because increases in the cost of education became too much of a financial burden for them. In light of the fact that some students could no longer be brought to the universities, some educators began to ask whether universities could be brought to the students.

Reports were generated to see if in fact universities could be brought to the students and the question was raised as to whether the effort should be limited to universities only. The result was the creation of the Commonwealth of Learning, which looked at education as a broadly based endeavour. The Centre was approved in principle by the Com-

\footnotetext{
* Those in attendance included Flora MacDonald, The Commonwealth of Learning; Howard Adelman, Director, Centre for Refugee Studies, York University; Susan Allen, Faculty of Environmental Studies, York University; Elizabeth Burge, Institutional Resources Unit, OISE; Barbara Burnaby, Department of Adult Education, OISE; Margaret Drent, Department of Political Science, York University; Marcela Durán, Faculty of Education, York University; Andrew Forbes, Faculty of Environmental Studies, York University; Marlinda Freire, Chief Psychiatrist, Student Support Services, Toronto Board of Education; Motoyo Kamiya, International Task Force on Literacy; Karen Kraft-Sloan, Faculty of Environmental Studies, York University; Lawrence Lam, Department of Sociology, York University; Michael Lanphier, Master, McLaughlin College, York University; Diana Lary, Department of History, York University; Rest Lasway, Department of Adult Education, OISE; Micheline Reid, Association of Canadian Community Colleges; Alex Zisman, Graduate Programme in Social and Political Thought, York University.
}

monwealth heads of government in Vancouver, British Columbia, in 1987.

Thirty million dollars in government grants from various Commonwealth countries were acquired to begin building the Centre. The Centre began operations in January 1989 and is based in Vancouver. It is composed of 12 professional staff, 10 to 12 support staff and is responsible to 50 Commonwealth countries with a total population of over 1.5 billion people. Therefore, resources are extremely limited.

For the purpose of operation, the centre has divided up the globe into four geographic areas: Asia , the Caribbean, Africa and the South Pacific.

The key personnel at the centre are all involved in distance learning. Therefore, a lot of expertise in distance education has been accumulated within a small group of people.

Experts from the centre meet with the ministers of education in their respective countries to ask what the priorities are for their country. They then 
sit down and figure out how the centre can get involved.

Some examples of possible involvement include the upgrading in the quality of nursing staff in Sri Lanka, the establishment of an Open University in Bangladesh, the upgrading of the skills of primary school teachers in scattered communities in Jamaica, and the establishment of an educational broadcasting system in Namibia.

Primarily, the Commonwealth of Learning is involved in taking education outside of the conventional classroom. In light of this fact, one of the proposals that I have made to the Commonwealth of Learning is to look at the possibility of helping refugees in refugee camps in Southern Africa. This proposal has now been accepted by the Centre.

According to the UNHCR, there is not a great deal being done in the area of literacy and literacy training for these people. There are huge refugee populations in Malawi and Zambia for instance. These people are a "captive audience" mostly made up of women and children.

\section{Marlinda Freire: It is important to find out what the refugees themselves perceive to be their basic needs and to let them define their own needs on a priority basis.}

We are currently looking at a couple of pilot projects. For example, we are in the initial stages of setting up a programfor Mozambican refugees in Zambia. I am trying to elicit from you and others an idea of how we can go about doing this. How do we get to them in an appropriate language? How can we get a hold of materials which have already been produced and have them adapted to the countries we are targeting?

\section{Basic needs priorities}

Marlinda Freire: One should first go out and consult with the beneficiaries because sometimes they express a need for types of aid which are unrelated to the one offered. It is important to find out what the refugees themselves perceive to be their basic needs and to let them define their own needs on a priority basis.

Flora MacDonald: We would go into the refugee communities first but we must remember that we are an educational institution and therefore must set things up under the mandate given to us by the Commonwealth Heads of Government. We have to operate within the realm of education. But one can do things involving work with people in the field of agricultural development or health.

\section{Factors affecting community-based participation}

Karen Kraft-Sloan: We should first go out and find why other similar programs have experienced low participation rates and see if there are social and cultural factors which bring about success or failure, so that they can be isolated and understood in the context of the project we are now talking about. We should also look at the way in which past programs have been implemented in order to avoid past errors; problems in the past may have been due to the fact that the program was not broad-based nor suited to the needs of the people.

\section{Elizabeth Burge: We need to empower refugees to take control of their own situation and not become passive recipients of international aid.}

\section{Empowerment}

Elizabeth Burge: We need to empower refugees to take control of their own situation and not become passive recipients of international aid.

Howard Adelman: People need to become agents of social change and begin to design their own programs. This is a critical matter and I cannot think of anyone in the field of refugee studies who is capable of designing such a program.

\section{Monitors}

Marcela Durán: There are distance education projects in Mexico initiated in the 1970s which used dif ferent native languages. Monitors from the community were trained and the native community together with the government designed the projects. It was very successful. Do you plan to use monitors?

Flora MacDonald: No definite plans have been made for the initial stage of the project but the question of monitoring would have to be an integral part of the project. However, unless there are monitors in place on an ongoing basis, simply having radio receivers and au- 
dio-visual materials in camps will not work. We need people to be animators $s$ well as tutors.

\section{Technology}

Rest Lasway: I am concerned about problems related to technology in a rural setting. In Africa technology is concentrated in urban centres and therefore only benefits urban people. Also many rural people are too poor to own a radio. Maybe we should first consult local experts in the target community because a lot of resources will be needed if the program is to remain rural-based.

Flora MacDonald: In Tanzania we have been out in the field talking to the Minister of Education who wants to establish an Open University. They asked for two things, a low voltage radio transmitter set up in order to get to all areas of the country, and the introduction of desk-top publishing so that they can do their own preparation of courses that suit their immediate needs.

\section{Contextual Issues}

Elizabeth Burge: I find myself thinking more about the contextual issues before one actually gets into putting together an actual program. For example, are the refugees located in one large geographic area? If they are, what are the logistics involved? Are we going to make use of any local community studies/proposals before we get into the use of radio/audio cassettes and other technologies?

I am also concerned about what refugees would like to get out of this program - is it education for integration into the host country?

Flora MacDonald: In response to your question my answer is that we are looking at the situation in terms of the refugees going back to their own countries. There is no question in my mind that people in refugee camps in Southern Africa want to get back to their own country. We have realized that these people are often taken advantage of when they return to their own country

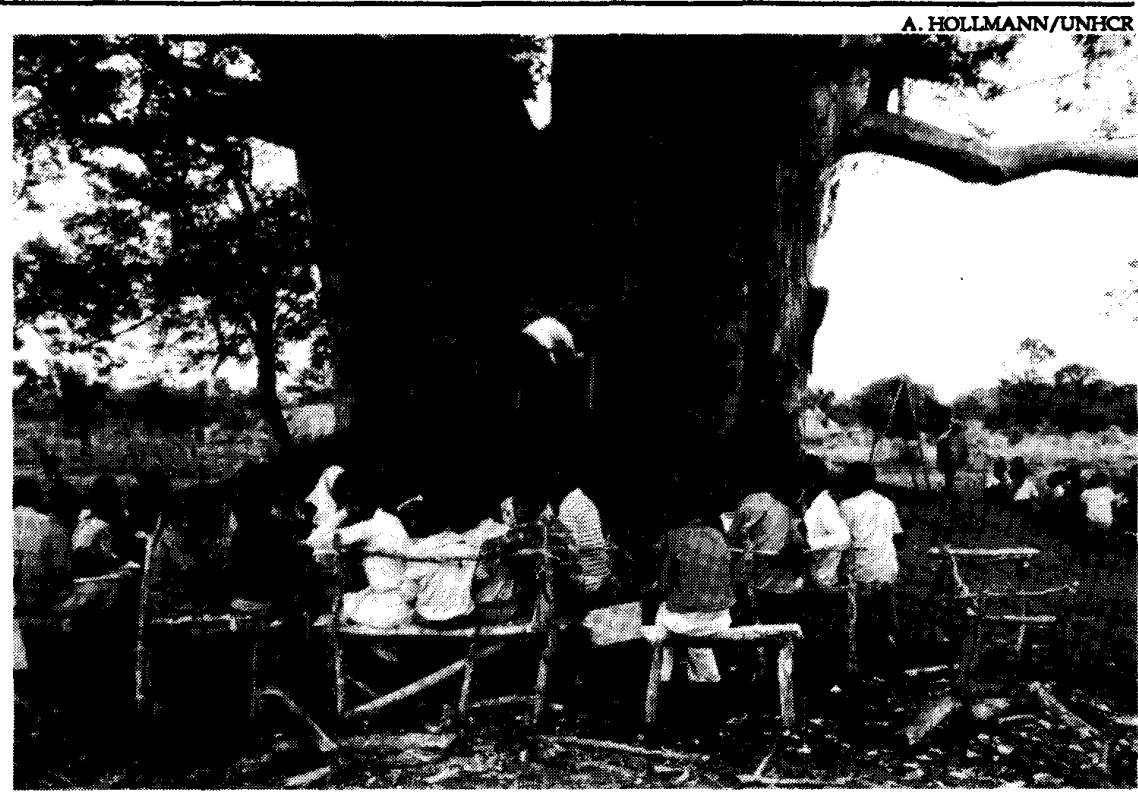

Mozambican refugees are eager to acquire some degree of literacy in Chifuga camp, Muanza District, Malawi.

unless they have some degree of literacy. We can try to avoid this by preparing them for when they go back. It is the same for any type of agricultural or health assistance that can be provided. These are the three things that are important as far as linking them to a literacy program is concerned.

If Mozambique returns to a normal situation it will apply to join the Commonwealth. Namibia has already joined. Refugees who were in Zambia acquired an educational advantage over those who remained in Namibia. However, the Commonwealth of Learning has been asked to continue working with refugees who have returned to Namibia from Zambia because while they possess educational skills which put them ahead of the black population in Namibia, they continue to exhibit real difficulties in reintegrating themselves into Namibian society.

\section{Pre-pilot Phase and Pilot Phase}

Howard Adelman: One of the things that we ought to discuss is who does the pilot? Does an outsider manage it or do we offer an opportunity for someone in Zambia with relevant skills to come here and spend four months at OISE and at the Centre for Refugee Studies? Do we ask the camp population to select somebody and we will provide a scholarship for them to come here rather than us figuring out what the program ought to be?

We could assess an orientation program. In this case Oxford could play a better role than we can to acquaint the student with the context of being a refugee which being a refugee does not always teach you. This person could get the larger awareness of some critical self-consciousness if they already had some skills in distance learning and literacy.

In a possible scenario, once the appropriate persons have been found, we would have to send them to Zambia to investigate the parameters of what we are to accomplish and then report back to us, so we can decide if the emphasis should be on distance education rather than on literacy. The persons would also get a briefing on refugees and whatever field they were lacking before they went. They would do particular studies and then go and survey the situation. They would also find people who would be able to work with the project.

Another problem is how to combine 
the three fields of knowledge: refugees, distance education and literacy.

Of the three fields, literacy is the most critical. A literacy person should be invited to come to Canada to study distance education and refugees and develop a set of parameters. This person would then go to Southern Africa and find someone to be their local partner. We would therefore have a prepilot as well as a pilot phase to the project.

There is also the question of the future location of refugees and how this would have an impact on the project.

There are a number of presumptions involved when talking about the location of refugees. Although camps are most suitable for the purpose of Western international assistance programs, only half of refugees are located in such settings. Therefore, we must

\section{Howard Adelman:} while camps may offer refugees training that they might not have otherwise had, they may also be made more welfare-dependent through such an experience. Those refugees who are self-starters may be better of in the long run than are those who are in camps. envision literacy as education for all despite the fact that camps are used as a focus for the project.

A second important issue is the impact upon refugees of the experience of being in a camp. Studies show that the most successful refugees are those who are located in camps. But care must be taken because institutions tend to attract people to a centre which may not be best suited to the needs of these refugees. That is to say, while camps may offer refugees training that they might not have otherwise had, they may also be made more welfare-dependent through such an experience. Those refugees who are self-starters may be better off in the long run than are those who are in camps.

We also can never predict where the refugees will end up. Past experience has shown that repatriated refugees who had been located in camps end up in advance of those who remained in the home country because they have had some time out - a few years sabbatical if you like - and have often had some kind of institutional support which people back home never had. Therefore, refugees ending up back home often find themselves playing a much greater leadership role. One has to think about skills they will need even though they may not now know what roles they will be expected to fulfill.

\section{Mother tongue literacy versus second language literacy}

Marcela Duran: There is a wealth of material on the Brazilian experience as well as literacy projects in Guinea Bissau, which is directly related to what you want to achieve in Zambia. It is also particularly appropriate because the material is in Portuguese.

Marlinda Freire: One problematic issue is a situation in which one is trying to educate a refugee to be literate in his/ her second language when $s /$ he is not even literate in the mother tongue. It is difficult to make people literate in English when they may not be literate in their own language.
Flora MacDonald: The Commonwealth of Learning is interested in English language literacy despite the difficulties involved in teaching second languages to individuals illiterate in their mother tongue.

Barbara Burnaby: It depends very much on the motivation of the person. Some people are highly motivated and become literate in English despite the fact that it may be extremely difficult. People succeed if given the appropriate program. Sometimes a bilingual program is needed where learning is in English with a lot of mother tongue support. Sometimes people just want to be able to write letters home so they need to be able to write in their own language.

I know of work being done in Asian refugee camp programs for people who expected to be sent to the US. These people had lived in a totally non-literate environment; they needed to learn things about their own language first so the Americans taught them to become literate in their own language before introducing English.

Marlinda Freire: I would like to know if there is any evidence which shows that becoming literate in a second language before becoming literate in mother tongue is successful. My investigations have led me to the opposite conclusion. 


\section{Available resources}

Marcela Durán: Information should be exchanged with the South because of the accumulated experience of the latter in literacy and in international development.

Flora MacDonald: The Commonwealth of Learning is interested in English language literacy despite the difficulties involved in teaching second languages to individuals illiterate in their mother tongue.

Namibia has seven major indigenous languages. The connecting language in the past was Afrikaans. Because the new government knew that it could not communicate very widely on the international scene with indigenous languages and Afrikaans, it declared English to be the official language of Namibia. They now face a major challenge in teaching their teachers English so that they can teach their students. Perhaps the same situation will occur in Mozambique since the primary language of communication in Southern Africa is English.

\section{The difficulty in reaching women}

Flora MacDonald: We also have an opportunity to work with women who don't have the same access to education in their home countries as males do.

Elizabeth Burge: Spousal sabotage occurs because men do not want women to be educated.
Flora MacDonald: We need information on the feasibility of this project. We need to know the factors to consider. I am trying to put together a database: I understand that the Association of Canadian Community Colleges has one. The United Kingdom has directed their contribution to the Commonwealth of Learning through their Open University, which is doing a database of distance learning materials in all the Commonwealth countries. It is a huge project to put together. India also has a huge amount of data on distance learning.

I have been in touch with the UNHCR to see what they are doing, if anything. They find their hands are with the task of organizing and operating camps. Only in Indonesia and Thailand have they organized adult literacy training. It has been a superficial thing which they introduced to keep people occupied. They did not find any great interest in the project among the refugees, particularly among the men.

My reason to go to the UNHCR was not so much to say "this is what you should be doing" as much as "this is what we are prepared to do in certain parts of the world. Please don't try and block us."

Diana Lary: There might be some people who have been working in Northern communities in Canada or working through the Inuit programs who might have some advice to offer.

Flora MacDonald: The Inuit Broadcasting Service is a very imaginative and successful venture. They are using the Northern satellite of the CBC when it is not in use for transfer of English language programs. They have also been developing a whole Inuit language service. Their service is now seen by Northern groups all over the globe as something to emulate. The Inuit Broadcasting Service is something people in Southern Canada do not know much about.

One of the first requests we receive in going to countries is for information on distance education. Teachers want to learn more about it and how to operate and maintain the facilities. In the Open
University in India teachers have not been trained in distance education so they want to set up an institution to train teachers in distance education.

Alex Zisman: Another source of access could be the International Council for Adult Education, based in Toronto, which has links with numerous educational networks all over the world.

Marcela Durán: Information should be exchanged with the South because of the accumulated experience of the latter in literacy and in international development.

Susan Allen: Judith Marshall's expertise on Mozambique could prove useful. Resources at the Center for Applied Linguistics in Washington, DC, the Society of Friends and CODE could also be tapped.

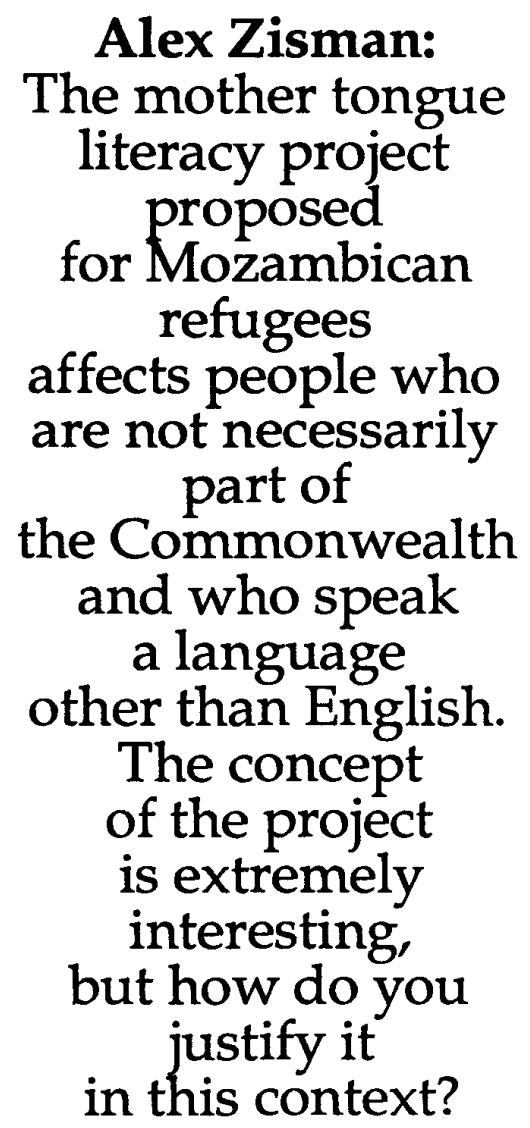




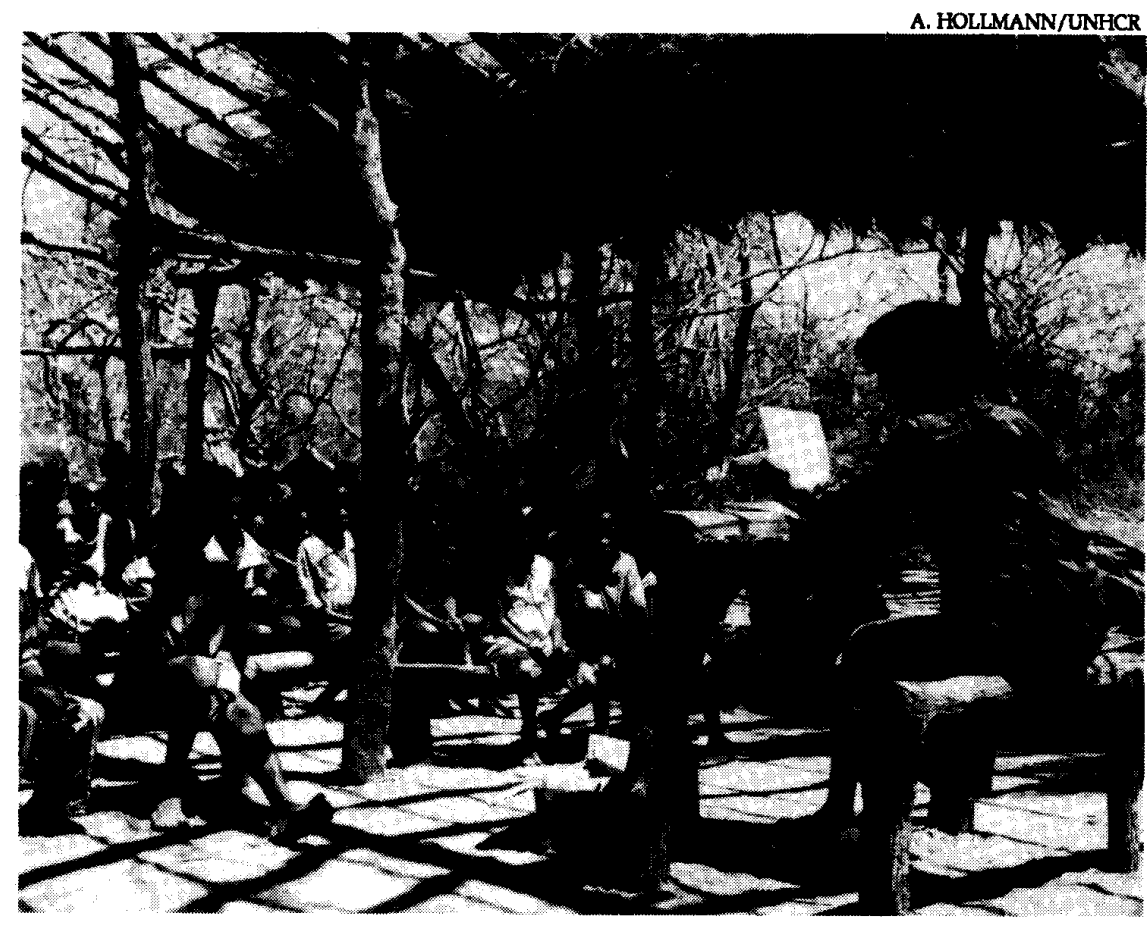

Volunteers from the Mozambican refugee community are chosen to staff the Ukwimi settlement preschool in Petauke District, Zambia.

\section{The Commonwealth of Learning as the appropriate vehicle}

Alex Zisman: One of the key factors that has to be considered is functional literacy and why a refugee wants to become literate. Literacy entails not just reading and writing. It is a question of functioning in society, of acquiring a sense of purpose and direction. Where do we want these newly literate refugees to function and how do we want them to function? They have to define this for themselves. This is a key motivational ingredient in the project. For this project to succeed there has to be an enormous grass roots component. We have to make the project rewarding for the refugees and they have to find the project rewarding for themselves.

I also have some concerns about the actual appropriateness of the involvement of the Commonwealth of Learning tongue literacy project proposed for in a project of this nature. The mother the future. This may be an opportunity to gain basic knowledge. The UNHCR could be doing it. The Commonwealth of Learning is particularly suited to do this since the UNHCR cannot and because the Commonwealth is networking among 50 countries. In the future, Western African problems may produce refugee influxes in neighbouring countries such as Nigeria for instance. The purpose of the project is therefore to gather information as well as to address the immediate situation.

\section{CAAS
Conference}

The 1991 conference of the Canadian Association of African Studies will he held at York University, Toronto, from May 16 to May 19, 1991. The general theme of the conference will be "Africa in the 1990s: Development with Democracy."

The 1990s offer the possibility that democratic rule will be spread throughout Africa. Will this trend to democracy continue, and will the new environment be better suited to development than the political climate of the 1980s?

Papers are invited from all disciplines, Mozambican refugees affects people who are not necessarily part of the Commonwealth and who speak a language other than English. Thus, the complications are built in already. The concept of the project is extremely interesting, but how do you justify it in this context?

Flora MacDonald: In response to the question regarding whether the Commonwealth of Learning has deviated from its intended purpose, I would say that there is no question, as I sit in Commonwealth leaders' meetings, that language is the unifying principle of the organization. You cannot ever leave questions of English language out. Also, these countries share the same legal and judicial systems. Training in the English language should therefore be a component of this Commonwealth-sponsored project. The basic reason for going in is to see how something like this could be carried out in a refugee community because there are probably going to be more, not less, refugee settlements in including the humanities and the arts. Authors are encouraged to address any aspect of Africa's current struggle for development, exploring both the constraints and the opportunities inherent in Africa's art, culture, ecology, economy, and sociopolitical traditions and institutions.

As in the case with all CAAS conferences, there will be many panels that are not on the theme of the conference but reflect instead the general membership of the Association. Secondary themes include environmental issues, famine and drought, refugees, AIDS, the African diaspora (especially Canada), history (Islamic Africa, slavery, etc.), cultural/artistic topics, literature, gender issues, racism in Canada, etc. All proposals are welcome.

All proposals must be accompanied by an abstract of 150 to 200 words. A final call for papers will be issued in December 1990. Please send all abstracts, enquiries and suggestions to: Paul Lovejoy, Department of History, 4700 Keele Street, York University, North York, Ontario M3P 1P3, Canada; Telephone: (416) 736-5883, Fax: (416) 7365834, E Mail: PLOVEJOY@YORKVM2. 


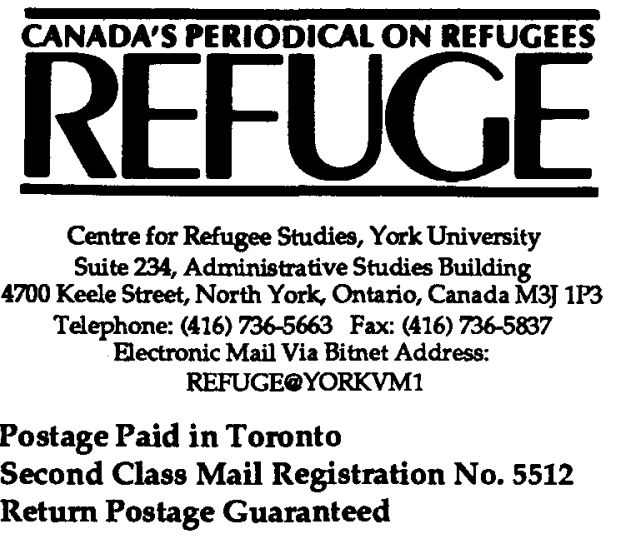

\section{CRS Named Centre of Excellence for Third World Development}

The Centre for Refugee Studies (CRS) at York University has been designated a "Centre of Excellence in International Development" by the Canadian International Development Agency (CIDA).

York has the largest concentration of scholars undertaking refugee research in Canada, while the CRS is one of the main centres of its kind in the world.
CIDA will provide approximately $\$ 5.2$ million over 5 years to York University to increase and integrate research projects in the areas of settlement, resettlement, repatriation and the law.

These research projects will be primarily geared to assisting refugees and improving the policies and programs of non-government and government agencies dedicated to serving the needs and responding to the rights of refugees.

The CIDA grant will enable the CRS to expand its research into the whole international refugee field. The funds will also contribute towards the publication of an annual survey and the establishment of a new program in refugee studies at York.

\section{Refugee Law Research Unit Publications}

The Refugee Law Research Unit has recently been established under the direction of James C. Hathaway as an operating Unit of Osgoode Hall Law School's Centre for Research on Public Law and Public Policy, and a partner of York University's Centre for Refugee Studies. Its primary goal is to promote understanding of the Convention definition of refugee status, and more generally to promote the humane application and progressive reform of international and Canadian refugee law.

Among the projects of the Unit, one of the most important is the preparation of a series of discussion papers on issues of refugee law. The first discussion paper deals with the recent decision of the
Federal Court of Appeal in the case of Patrick Francis Ward, a citizen of the United Kingdom and Ireland whose claim to refugee status was ultimately denied by Canada. The decision is extraordinary in its breadth, dealing with notions of agents of persecution and availment of protection, dual nationality, and the definition of membership of a particular social group. Moreover, it has important jurisprudential value, as the majority judgement is complemented by a thorough concurring decision, which read together present most of the major concerns in relation to these three aspects of Convention refugee status.

It is hoped that this discussion paper will be of assistance to advocates involved in the process of refugee determination, to decision makers, and ultimately to those charged with the reform of policy in this field. The Refugee Law Research Unit welcomes the comments of those who read this discussion paper, and look forward to a continuing dialogue with individuals and groups concerned to ensure the continuing viability of the refugee protection system.

Other pending publications include: Agents of Persecution: When is There a Failure of State Protection?, Assuming Refugee Claims Arising from Civil War and Refusal to Perform Military Service as the Basis for a Claim to Refugee Status. 